\title{
Поэзия Бродского как «синоптический дневник» synoptikos (греч.) - обозревающий все вместе*
}

\author{
Abstract \\ Time and Weather in Joseph Brodsky's Poetry
}

The article focusses on the poetry of Joseph Brodsky. The researcher looks at the poet's interest in the seasons of the year and nature's transformations in different seasons. Poems featuring the intertwining motifs of "time" and "weather" are analysed in chronological order. The researcher aims at exploring in detail the characteristics of the imagery, as well as reconstructing the world of Brodsky's poetic self, where anthropomorphic nature plays an important artistic role.

Keywords: Joseph Brodsky, Russian poetry, literature and nature.

Особой приметой поэтического мира Иосифа Бродского является тонкое чутье погоды его лирического героя. В поэзии Бродского, а и во всем его творческом наследии, существенную роль играют категории «время» и «пространство», и его исследователи не раз останавливали свое внимание на этой проблеме. ${ }^{1}$

Время в разных своих измерениях и смыслах неизменно становится для поэта поводом размышлений, а образы, в которые оно воплащается, являются компонентом картины мироздания. На протяжении всего творчества Бродского лирический голос авторского «я» повествует о времени, как бы «регистрируя» все детали о переменах погоды в круговороте сезонов.

В данном тексте сделана попытка реконструкции поэтических описаний погоды у Бродского, которые нами воспринимаются как некий Синоптический дневник.

Несомненно, фокусом поэтического мира Иосифа Бродского является человек, и точнее - мыслящее, чувствующее и выражающее при помощи

* Римечания Словарь иностранных слов, «Русский язык» 1981, с. 467.

1 «Хронотоп» в поэзии Иосифа Бродского исследуется с разных аспектов: это и мотивы прошлого, настоящего и будущего, это и тема города, и тема жизни и смерти и т.д. 
языка свои суждения и эмоции существо поэта, которое наделено способностями общаться с природой, со стихиями - такими, как воздух, вода, огонь, с вещным миром. Поэт ведет с ними беспрерывный диалог, они являются частью его динамичного мировосприятия.

Раскроем творчество Бродского на страницах Синоптического дневника. На них запечатлены состояния и перемены погоды, выявлены со своими характерными приметами и причудами сезоны. Особое значение для Бродского имеет зима. Поэт неоднократно припоминает и себе самому, и своим действительным и воображаемым собеседникам, что он с Севера, а это значит - с земель зимы, снегов, холода. В своем эссе Письмо Горацию повествователь толкует своему адресату, что он «гипербореец», приехавший на землю, унаследовавшую родину Горация, «из Гипербореи двадцать два года тому назад». ${ }^{2}$

Зима входит в состав заглавий ряда стихотворений Бродского и является точным определителем времени лирического сюжета: Зимняя сватьба, Зимняя почта, Зимный вечер, Эклога 4-ая, зимняя и т. П. Подход к толкованию погоды и в частности зимы у Бродского довольно разный в отдельных стихотворениях. Многие исследователи заинтересованы метафорическими значениями сезонов и раскрывают «семантический ореол» этого, столь существенного для Бродского сезона. ${ }^{3}$

Нами проводятся наблюдения над функционированием описаний погоды, сделанных поэтом, но без установки на метафорические и аллегорические коннотации. Суть анализа - раскрыть эти описания как своеобразные «сводки о погоде» и таким образом показать их роль для структурирования стихотворения. Выбрав эти «сводки» объектом анализа, мы хотели бы выявить то, как они проявляются в контексте данного стихотворения.

В этих «сводках» лирический герой сообщает ровным голосом приметы погоды, но, указывая на них, он как бы материализирует свое существование. Цепляясь за конкретный момент, он таким способом хочеть сказать себе, что он жив, что он есть в данном, реальном времени.

Перед тем, как приступить к анализу конкретных произведений, нам хотелось бы выявить еще одну характерную особенность, наблюдаемую в произведениях из Синоптического дневника. В структуре поэтического текста описания, названные нами «сводками погоды», воспринимаются и как авторские ремарки. Этот «паратекст» драматургических произведений используется поэтом, ибо вставляя его в корпус стихотворения, он затверждает позиции авторского «я», чей голос организует акустику текста. Уточняя таким образом свою «точку зрения», ${ }^{4}$ лирический герой подчеркивает более отчетливо свое присутстве в сюжетной раме произведения. Как в своих эссе,

2 И. Бродский, Письмо Горацию, http://brodsky.ouc/pismo-goratsiyu.html [7.04.2013].

3 «Зима» и вообще «время» и их символические и метафорические значения для поэзии Бродского исследются такими авторами как: В. Куллэ, Л. Лосев, А. Уланов, В. Губайловский, О. Глазунова, А. Ранчин, М. Халимбекова и многие другие.

4 «Точка зрения» как проблема композиции рассамтривается подробно в книге Б. Успенского «Поэтика композиции». СПб.: Изд. «Азбука» 2000. 
так и в стихах, Бродский часто начинает с какого-нибудь конкретного факта и, исходя из него, ассоциативно развивает дальше суть произведения.

В стихотворении Горение, например, точкой отсчета являются первая и вторая строки первой строфы: «Зимний вечер. Дрова / охваченные огнем...». Точно как в драматургическом тексте, автор безразличным голосом вставляет свои замечания, описывая время действия и интерьер. Но у Бродского в следующем стихе мысль отскакивает, какая-то неведомая читателю ассоциация является толчком к неожиданному сравнению: «как женская голова /ветренным ясным днем». ${ }^{5}$ «Точка зрения» лирического «я» переставляется от конкретного к воображаемому, и с того момента разворачивается исполненный драматизмом любовный сюжет.

Стихотворение Горение перекликается с Пастернаковской Зимней ночью, включенной в последней главе романа Доктор Живаго. И в том, и в другом стихотворении представлен «жар соблазна», но в тексте Бродского более сильно ощущается какая-то отрешенность, даже ожесточенность отношений участников любовного акта:

Так рвутся, треща, шелка,

обнажая места̀.

То промелькнет щека,

то полыхнут уста.

Так рушатся корпуса,

так из развалин икр

прядают, небеса,

вызвездив сонмы искр. ${ }^{6}$

Граничность случившегося, его отмеренность и обреченность, внушаются Бродским последней строфой, которая возвращает лирического героя в реальность окружающего. Рамой поэтического рассказа становится «ремарка» отрезвления: «холод, рассвет, снежок...».

Развернутую картину зимы Бродский рисует в своей четвертой Эклоге. Это стихотворение является объектом многих анализаторов. ${ }^{7}$ Произведение состоит из 14 частей, написал его Бродский в 1977-ом году. Размышления лирического героя, подводившего итоги, осознав, что «жизнь моя затянулась», - суть содержания. Параллельно с процессом кропотливого себепознания (как поэт писал в другом стихотворении: «и себя постигаешь в любом естестве») или самораспада, Бродский последовательно и неизменно регистрирует характеристики погоды, веря в то, что время идет своим чередом. Первая часть Эклоги начинается с суждения: «Зимой смеркается сразу после обеда», а девятая - с заключения: «В феврале чем позднее, тем меньше ртути». Наряду с этими конкретными наблюдениями, проведенными как

5 Все цитаты в этом исследовании приводятся по изданию: И. Бродский, Осенний крик ястреба, СПб.: ИГ «Азбука - классика» 2009. В дальнейшем указано сокращение ОКЯ и страницы. Тут стихотворение на с. 125-126. См. и Б. Пастернак, Собрание сочинений в пяти томах, «Художественная литература» 1990, т. 3, с. 526.

6 Сравним у Пастернака: «Скрещенья рук, скрещенья ног, / Судьбы скрещенья...».

7 См. и таких исследователей как О. Глазунов, А. Ранчин, Т. Глебович, Б. Шерр и др. 
бы беспристрастным свидетелем хода времени, развивается сложный текст - монолог, вскрывающий сущность авторского «я». Данный анализ, однако, целеположен выбранной темой и не распространяется на изучение внутренного мира лирического героя. Стратегия текста направлена на выявление тех «сводок», которыми иллюстрируется специфический прием Бродского - переход лирического голоса от ровных, сдержанных интонаций, запечатлевающих случайные и несущественные вещи, к горечи и к восторгу.

Этот прием встречается и в стихотворении Метель в Массачусетсе (1991). Оно начинается с констатации: «Снег идет - идет уж который день», ${ }^{8}$ которая подтверждается в последней строфе повторением: „Эх, метет, метет». И в этой раме поэт разворачивает «свод» переживаний пребывающего в одиночестве и тишине лирического героя.

Следуя за ходом поэтического календаря Бродского, направим внимание к следующему сезону, сменяющему зиму. Весна в поэзии является устойчивым символом молодости, надежды, пробуждения к новой жизни. Такой подход к весне применяется Бродским в стихотворениях Стихи в апреле (1969) и Восславим приход весны! (1978). Радостное пробуждение после скованности земли и людей зимней стужей, снегами и морозами, приводит в восторг лирического героя. Весна - «суть перемен», она восхищает поэта. Нельзя утверждать, что такие лирические интонации доминируют в поэтическом наследии Бродского. Наоборот. Наблюдается фреквентность «зимних» сюжетов и «скованность» эмоций. Этим можно объяснить и сравнительно ограниченное число стихов о весне, на фоне присутствия других сезонов в поэзии Бродского. Стремлясь к более исчерпательному облику «Синоптического дневника», приведем пример из стихотворения На возвращение весны, написанного в 1994 г. В нем лирический герой осознает тривиальное: у времени неизменный и необратимый ход. Но параллельно с мыслью об этом, в его сознании возникают странные вопросы:

\footnotetext{
Мы все влюблены в астрономию, в космос вообще, в безвредную

пляску орбит, колец, эллипсов с ихней точностью.

Но входишь, бывало, в обшарпанную переднюю

и прежде, чем снять одежду, бесцельно топчешься.

Что если небесное тело в итоге не столько кружится,

сколько просто болтается без толку - что, на практике,

выражается в том, что времени года лужица

приятна своей бесформенностью, не говоря - галактике. ${ }^{9}$
}

В процитированных строфах не наблюдаются разыскиваемые нами «сводки о погоде». В этом стихотворении поэт заинтересован потоком времени, который воспринимается как очевидный, но, как-бы нечаянно, лирический герой проникается вопросом о смысле человеческих идей. То, что нас радует, что помагает возвыситься над сиюминутным и банальным - это вера в «великий промысел», в неизменный порядок мироздания. Известны слова Канта о том, что две вещи наполняют его изумлением: «звездное небо

\footnotetext{
Бродский И. ОКЯ, с. 384.

9 Ibid., c. 509.
} 
надо мной» и «моральный закон во мне». В этих словах и удивление, и благоговение человека, ощутившего себя частью великого целого. Но лирический герой Бродского отклоняется от всеобщего восторга и внезапно, и как будто мимоходом, наталкивается на открытие, что, может быть, окружающий его космический порядок - «бессмысленное болтание без толку». По мере его восприятий, однако, это и шанс для неупорядоченных вещей, надежда нестандартного, незначительного, мелкого стать „приятным». Таковой может оказаться даже «бесформенная» весеняя «лужица».

У позднего Бродского все заметнее становится его внимание, а можно прибавить - его симпатия к какой-то расплывчатости пейзажа. Как будто в глазах авторского «я» неожиданно «помутнело», и острота и точность геометрии вещного мира «растекается». Еще в 1989 г. Бродский написал замечательное стихотворение Вечер. Развалины геометрии..., воспринимаемое как элегическое «in memoriam» конкретности и четкости очертаний. Наступил момент, когда смываются все границы и «человек отличается только степенью отчаянья от самого себя». ${ }^{10}$

Похожую «точку зрения» поэт применяет и в стихотворениях Пейзаж с наводнением (1993), где «повсюду размытое устно-письменно, сверху - рваное облако, и ты сидишь в воде...» ${ }^{11}$ и Воспоминание (1995), в котором пейзаж нарисован приемами акварельной живописи:

И за̀полночь облака, воспитаны высшей школой расплывчатости или просто задранности голов, отечески прикрывали рыхлой периной голый космос от одичавшей суммы прямых углов. ${ }^{12}$

В упомянутых стихотворениях намечаются и другие мотивы, но наш поток рассуждений не будет отклоняться. Этим упоминанием была затронута характерная особенность поэтики Бродского.

В стихотворении Воспоминание проступает следующий сезон, особенно любимый Бродским - лето. Оно выражено метонимией «глухонемая зелень». К этому времени года поэт сильно привязан. Лето для него - контраст зимы, время освобождения от скованности. Оно приводит в восторг наблюдателя своими красками, теплом, динамикой жизни.

В данном тексте не применяется статистический анализ, высчитывающий сумму написанных о каждом сезоне стихотворений, но знакомство с поэзией Бродского дает основания утверждать, что после зимы приоритетными для него являются лето и осень.

У Бродского есть две Эклоги (несмотря на то, что он их обозначил как «4-ая» и «5-ая») - «зимняя» и «летняя», которые воспринимаются антитезисно. Скованности зимы, когда «сильный мороз суть откровенье телу о его грядущей температуре», поэт противопоставляет лето, когда все движется, шумит, «кипит» и «пестрится». «Летнюю» Эклоу Бродский написал четыре

$\begin{array}{ll}10 & \text { Ibid., c. } 289 . \\ 11 & \text { Ibid., c. } 447 . \\ 12 & \text { Ibid., c. } 510 .\end{array}$ 
года после «зимней». Объектом наших наблюдений тут является не жанр произведения - диалог с римскими образцами этой поэтической формы, а присутствие «сводок о погоде». Они введены в текст и посредством них постигается контрастность поэтических интонаций. В этой Эклоге Бродский удивляет читателя своим поэтическим словарем. Поэт «откопал» совершенно неожиданный лексикальный пласт - сущее предизвикательство для переводчиков со своим обилием 300-и ботанических терминов. Это стихотворение - гербарий. Вся первая часть - перечень названий трав: «злак и плевель»:

\footnotetext{
Жизнь - сумма мелких движений. Сумрак в ножках осоки, трепет пастушьих сумок, меняющийся каждый миг рисунок конского щавеля, дрожь люцерны, чабреца, тимофеевки - драгоценны для понимания законов сцены. ${ }^{13}$
}

На смену этой «флоры» в третьей части приходят энтомология и орнитология. И этого «задыхающегося“ перечня перебивают, время от времени, восклицания лирического «я»: «Лето!». В этот «омут» слов, однако, вписано несколько лаконичных «сводок». Совершенно равнодушным голосом герой отмечает например: «Душный июль! Избыток зелени и синевы - избитих форм бытия». Таким образом постигнут совершенно неповторимый ритм стихотворения и соответственно - ритм бытия летом. «Словесными водопадами» изображена картина лета, когда все спешит, радуясь теплу и солнцу. У Бродского обрисован и другой ритм летней жизни - ленивый и замедленный. В стихотворении Посвящается Чехову (1993) повторяется почти та же «ремарка» из Эклоги: „Душные летние сумерки...», но за ней следует новая находка ассоциативного мышления автора: «близорукое время дня». Уже знакомая из других стихотворений Бродского «размытость» очертаний применяется и тут как прием. В пейзаже сниженной ясности предметы теряют свои очертания, звуки «гаснут», в доме восцарилась тишина, которая перебивается отрывочными «аккордами, взятыми наугад». Самь рояль как бы «молчит», что оригинально представлено метафорой: «рояль чернеет в гостиной, прислушиваясь к овации жестких листьев боярышника...». ${ }^{14}$

В этой картине подтекстно звучит внушение о размытости очертаний людей и предметов в этой захолустной и скучной жизни, с мелкими желаниями и отрывочными, бессвязными (никчемными) мыслями.

Отклоняясь от темы, не можем не отметить, что в этом воскрешенном Бродским мире чеховских героев, подчеркивается «сумрачность», когда «близкое [...] сходится с чем-то с далью», но самой дали и в прямом, и в переносном смысле, не видно и даже звезды находятся не на своем устоявшемся месте - на небе - они в саду. Но это не означает, что люди «поймут их». «Близорукость» времени перенеслась на людей.

\footnotetext{
13 Ibid., c. 249.

4 Ibid., c. 436.
} 
Лето у Бродского получает разные характеристики. В его «летнем календаре» особое место занимают «июльские и августовские стихи» ${ }^{15}$, такие как Августовские любовники (1961), Роттердамский дневник (1973), Шорох акации (1975), Сидя в тени (1983), Дождь в августе (1988), Облака (1989), Август (1996) и др.

Все эти стихотворения не написаны одной манерой. Голос лирического героя звучит в разных тональностях, но во многих из них можно найти интересующие нас «ремарки», о которых шла речь выше.

Примечательным примером о том, как поэт вводит в текст свои «сводки о погоде», является стихотворение Роттердамский дневник. Бродский написал его на следующий год после своего прибытия на Запад. В нем он затронул неизменно интересующую его тему времени. Человеческие судьбы и история продуманы поэтом, который остро воспринимает не только проявления современности, но и следы прошлого. «Три десятилетия» тому назад в этом городе бушевала война. Мысли лирического «я» перебрасываются с настоящего на прошлое, в его сознании постоянно возникают параллели:

Июльский полдень. Капает из вафли

на брючину. Хор детских голосов.

У Курбюзье то общее с Люфтваффе,

что оба потрудились от души

над переменой облика Европы. ${ }^{16}$

Чувствительность к классическим выражениям эмоциональных состояний читателя наверно заденет совершенно неординарная ассоциация Бродского. Военная тема (особенно в русской литературе XIX и XX-ых вв.) воплощается в художественных произведениях главным образом высокой патетикой или элегическими интонациями. В стихотворении Бродского, однако, эта тема интерпретируется контрастом между высоким и обыденным, выраженным перекрестной рифмой. Бродский слова из двух разных лексикальных рядов: «вафель» и «Люфтваффе», которое имеет использует грозные коннотации. Такое «знакомство» (по словам О. Мандельштама ${ }^{17}$ ) воспринимается неоднозначно. В этом поэтическом жесте просвечивает пресловутая «рассудочность» Бродского, из-за которой его не раз критиковали. Один из самых явных оппонентов Бродского-поэта был А.(л.) Солженицын, которого поэтическая манера Бродского откровенно раздражала: «Чувства Бродского, - писал Солженицын, - во всяком случае выражаемые во сне, почти всегда - в узких пределах неистребимой сторонности, холодности, сухой констатации, жесткого анализа». ${ }^{18}$

15 Август - один из летних месяцев, о котором пишут многие русские поэты. Этой теме повящена и моя статья «Поэты и сезоны», включенная в сборник Шуменского университета «Календарь в литературе», 2013 (готовится к печати).

16 И. Бродский ОКЯ, с. 160.

17 О «знакомстве» слов говорил О. Мандельштам. См. Воспоминания Анны Ахматовой об О.Э. Мандельштаме, http.//anna.achmatova.com/tvorchestvo/mandel.htm [18.04.2013].

18 О критике А. Солженицына см. у Б. Парамонова, http://www.svoboda.org/content/ transcript/24203001.html [24.04.2013]. 
Солженицын, который до конца своего творческого пути оставался «верноподанным» классической манере письма, не смог принять модернисткого подхода Бродского, для мировосприятия которого важную роль играли самоирония и ироническая дистанция. В рассматриваемом стихотворении основная нота авторского голоса выражает желание лирического «я» остаться сдержанным «регистратором» увиденного, почувствованного, пережитого. Таким образом, лирический герой как бы старается не мешать восприятиям читателя и в этом выражается лишний раз его любовь к свободе. Его стремление быть толерантным автором, держать эмоциональную дистанцию, предоставляет читателю возможность общаться с текстом без внушений. Автор не инспирирует читателя. В своей «Нобелевской лекции» Бродский говорил: «Оно (искусство - Р.Е.) вольно или невольно поощряет в человеке именно его ощущение индивидуальности, уникальности, отделенности - превращая его из общественного животного в личность [...]. Произведения искусства, литературы в особенности и стихотворение в частности, обращается к человеку тет-а-тет, вступая с ним в прямые, без посредников, отношения [...]. Эстетический выбор всегда индивидуален, и эстетическое переживание - всегда переживание частное». ${ }^{19}$

В Роттертамском дневнике „ремарки» строят корпус стихотворения. Первая строфа начинается со стиха: «Дождь в Роттердаме. Сумерки. Среда»будто в карманной книжке герой сделал мелкую запись. В первой «сводке указывается на погоду, на место и на конкретное время, во второй - которую мы уже частично процитировали - указывается сезон: «Июльский полдень». Картина времени расширяется, поэт прибавляет новые подробности, передвигаясь мысленно по мосту прошедших лет от минувшего к настоящему. Кончился день, но прошло и тридцать лет. Жизнь всевластна, она идет, следуя за своими логическими и алогическими извилинами. Современным людям предоставлена возможность время от времени подумать о том, что было, осознавая и свой шанс быть:

Ночь. Три десятилетия спустя

мы пьем вино при крупных летных звездах

в квартире на двадцатом этаже -

на уровне, достигнутом уже

взлетевшими здесь некогда на воздух.

Конечность человеческого времени глубоко осознана Бродским, и это определяет его восприятие круговорота сезонов. Они вращаются, подвластны космическим законам, и за летом, с которым людям никогда не хочется расставаться, неизбежно следует осень. Это подмечено, как всегда точно, в стихе: Кончится лето. Начнется сентябрь. Наступает осень, которую поэт воспринимает, как и другие сезоны, неоднозначно. В «ремарках» «осенних стихотворений» звучат беспристрастные наблюдения над погодой, но осень является и символом заката, увядания, конца. К осени Бродский особенно

19 Бродский И. Нобелевская лекция, http://lib.ru/BRODSKIJ/lect.txt [18.04.2013]. 
чувствителен в своих стихотворениях. Нет возможности перечислить их полный свод, но особое внимание заслуживают такие стихи, как: Осенью из гнезда (1964), Осенний крик ястреба (1975), Полонез: вариация (1981), Иския в октябре (1993), Она надевает чулки, и наступает осень...» (1993), Осень - хорошее время года... (1995) и др.

Осень имеет в поэзии Бродского разные лица, исполнена разными звуками. Этот сезон означает прощанье. Октябрь в Коннектикуте (Осенний крик ястреба) уже охвачен холодом, земля готовится к зимнему замиранию, и только летающая птица олицетворяет неустанное движение, которое воображение лирического героя превращает в звук и улавливает, как он «пахнет апофеозом». Таким образом постигается синтез ощущений.

Осенью природа подвластна переменам: деревья раздеваются, а люди наоборот - «она надевает чулки...». В стихотворении, начатом с заключения «осень - хорошее время года...», посредством сравнений и метафор дается характеристика осени. Это пора замеркания, когда прошло еще одно «лето Господне», и мир готовится застыть и погрузиться в молчании:

Остановись, мгновенье, когда замирает рыба

в озерах, когда достает природа из гардероба

со вздохом мятую вещь и обводит оком

место, побитое молью, со штопкой окон. ${ }^{20}$

Вся строфа - одни сплошные метафоры. Императив первой строки сильно наталкивает на сравнение с возгласом доктора Фауста, который воскликнул у Гете: «Остановись, мгновенье, ты прекрасно...». У Бродского, однако, мгновенье не прекрасно. Осенью пейзаж «штопанный» и «латанный», подчиненный имманентностям сезона. Думая о погоде, поэт воспринимает ее как независимую от человеческой воли сущность, она самостоятельна и неподвластна людям, и поэтому лирический герой утверждает: «меня упрекали во всем, окромя погоды...». В одном из поздных своих стихотворений «После нас, разумеется, не потоп...» Бродский рассуждает об этой отмежеванности человеческого времени от времени погоды. Только в «царстве справедливости» можно ожидать, что «климат [...] будет носить характер / умеренного, с четырьмя временами года, / чтоб холерик, сангвиник, флегматик и меланхолик / правили поочередно...». ${ }^{21}$

Все более ощутимой становится в поздних стихотворениях Бродского отстраненность лирического «я» от объекта наблюдения, от окружающих вещей, природных картин и условий погоды. O «размытости» пейзажа уже упоминалось. В заключении прибавим несколько слов об эффекте отсутствия, изъятия лирического «я» из сюжета, из пейзажа в поэтическом тексте. В стихотворении Остров Прочида, написанном в Венеции, в ноябре 1994ого года (т.е. осенью), этот эффект применяется полностью. Структура стихотворения состоит из лаконических замечаний, произносимых каким-то бесстрастным голосом:

\footnotetext{
20 И. Бродский ОКЯ, с. 498.

21 Ibid., c. 494.
} 
Захолустная бухта: каких-нибудь двадцать мачт.

Сушатся сети - родственницы простыней.

Закат. Старики в кафе смотрят футбольный матч.

Синий залив пытается стать синей.

Чайка когтит горизонт, пока он не затвердел.

После восьми набережная пуста.

Синева вторгается в тот предел,

за которым вспихивает звезда. ${ }^{22}$

$\mathrm{Bce,} \mathrm{о} \mathrm{чем} \mathrm{говорилось} \mathrm{в} \mathrm{этом} \mathrm{тексте,} \mathrm{о} \mathrm{«ремарках»} \mathrm{и} \mathrm{«сводках»,} \mathrm{собрано} \mathrm{в}$ данном стихотворении. Авторский голос держит одну ноту и произносит отчеканенные строки. Лирический герой старается только суммировать то, что случается без него. Он делает «примечания», как это выражено в названии его стихотворения Примечания к прогнозам погоды. Таким образом, лирический герой Синоптического дневника Бродского выявляется как „обозреватель, обнимающий взглядом все вместе», раскрывающий ненавязчиво тот промысел, который направляет людей и мироздание.

22 Ibid., c. 508. 